\begin{tabular}{|l|l|l||}
\hline \multicolumn{2}{|c|}{ PublisherInfo } \\
\hline \hline PublisherName & $:$ & BioMed Central \\
\hline \hline PublisherLocation & $:$ & London \\
\hline \hline PublisherImprintName & $:$ & BioMed Central \\
\hline \hline
\end{tabular}

\title{
Forensic genomics
}

\begin{tabular}{|l|l|l||}
\hline \multicolumn{2}{|c|}{ ArticleInfo } \\
\hline \hline ArticleID & $:$ & 4625 \\
\hline \hline ArticleDOI & $:$ & $10.1186 /$ gb-spotlight-20021031-01 \\
\hline \hline ArticleCitationID & $:$ & spotlight-20021031-01 \\
\hline \hline ArticleSequenceNumber & $:$ & 291 \\
\hline \hline ArticleCategory & $:$ & Research news \\
\hline ArticleFirstPage & $:$ & 1 \\
\hline \hline ArticleLastPage & $:$ & 3 \\
\hline \hline & & RegistrationDate : 2002-10-31 \\
ArticleHistory & $:$ & OnlineDate \\
\hline \hline ArticleCopyright & $:$ & BioMed Central Ltd2002-10-31 \\
\hline \hline ArticleGrants & $:$ & \\
\hline \hline ArticleContext & $:$ & 130593311 \\
\hline \hline
\end{tabular}


The guilty party who killed five people and caused widespread disruption last fall by sending anthrax through the mail is still at large. But the next time bioterrorists strike, they might find it harder to elude capture owing to a technique called 'forensic genomics' in development at The Institute for Genomic Research (TIGR) in Rockville, Maryland. The new approach, which could aid bioterrorism investigations and also have wipespread applications in medical diagnostics, was described Tuesday by Steven Salzberg, TIGR's chief of bioinformatics, at a Massachusetts Institute of Technology (MIT) symposium on 'Biological Challenges to Humanity.'

TIGR was drawn into the anthrax-mailings case in October 2001 at the behest of the National Science Foundation (NSF) because of the institute's expertise in genome sequencing and the fact that, at the time, it had nearly finished sequencing the genome of the familiar Ames strain of anthrax.

With a $\$ 200,000$ NSF grant, TIGR assembled what Salzberg termed "a bioinformatics SWAT team" to fully sequence the Ames genome and sequence the genome of the unidentified strain that killed a Florida man, Robert Stevens, the first victim of the mail attacks. The next step was to align the two genomes, searching for subtle genetic differences that might betray the laboratory from which the deadly anthrax emanated, facilitating the hunt for culprits. This type of comparison had never been attempted before and certainly not in the context of a criminal investigation.

The technique was successful, up to a point, as the TIGR team led by Claire Fraser, Timothy Read, and Salzberg was able to distinguish between isolates that were previously indistinguishable. Although they could not trace the lab of origin, because the 'attack' strain was so closely related to the reference strain, they still managed to identify 60 distinguishing genetic markers, including 11 validated singlenucleotide polymorphisms (SNPs). Salzberg claims the approach has advantages over the traditional method of comparing two strains, which involves looking for variable number tandem repeats (VNTRs), small repeated DNA segments. The drawback of VNTR analysis, said Salzberg, "is that it only samples a limited portion of the genome. Whole-genome sequencing is slower and more expensive, but that disadvantage is vanishing as sequencing becomes faster and cheaper."

TIGR researchers are now sequencing 14 more anthrax strains, looking for SNPs in all of them. "If another anthrax attack occurs, we'll have thousands of markers to draw on," Salzberg said. Ultimately, they hope to pack all that information onto a single DNA chip that will enable people to differentiate between 1,000 or more anthrax strains at a time. Although the analysis last fall took many weeks, he added, "with a chip in hand we could do it in a minute and be a lot more precise."

The approach is by no means limited to anthrax, as it could be used for testing other biowarfare agents and natural pathogens too. Salzberg said he is anxious to see this technology benefit human health in the broadest possible sense, taking on the most important human pathogens such as tuberculosis, Streptococcus, pneumonia, cholera, and the most dangerous E. coli strains. There will be significant upfront costs for sequencing, he acknowledged, but once that's done, a DNA chip could be used to pinpoint the source of bacterial infection from hundreds of different strains. That would represent a huge advance in medical diagnostics, and the technology already exists, he told us. 
Cost remains the biggest barrier. "If such a chip were mass-produced today, each test would run about $\$ 200$, which is too much for a kid with a sore throat," Salzberg said. If that cost can be reduced 10-fold, he believes this technology could transform the practice of medicine.

\section{References}

1. The Institute for Genomic Research, [http://www.tigr.org/]

2. Massachusetts Institute of Technology, [http://www.mit.edu]

3. Whitehead Symposium program, 'Biological Challenges to Humanity: Emerging and Re-emerging Pathogens', [http://www.wi.mit.edu/cee/cee_conf_symp02_pro.html] 